\title{
Carnets
}

Revue électronique d'études françaises de l'APEF

Première Série - 4 Numéro Spécial | 2012

Invasions \& Évasions

\section{Invasões Francesas e Pré-Romantismo Português - Francofobia e Anglomania}

Álvaro Manuel Machado

\section{OpenEdition}

1 Journals

Edição electrónica

URL: http://journals.openedition.org/carnets/7262

DOI: 10.4000/carnets.7262

ISSN: 1646-7698

Editora

APEF

Edição impressa

Data de publição: 1 Junho 2012

Paginação: 29-43

Refêrencia eletrónica

Álvaro Manuel Machado, «Invasões Francesas e Pré-Romantismo Português - Francofobia e

Anglomania », Carnets [Online], Première Série - 4 Numéro Spécial | 2012, posto online no dia 23 junho 2018, consultado o 01 maio 2019. URL : http://journals.openedition.org/carnets/7262 ; DOI : 10.4000/ carnets.7262

\section{(c) (1) (8)}

Carnets est mis à disposition selon les termes de la licence Creative Commons - Atribution - Pas d'utilisation commerciale 4.0 International. 


\section{INVASÕES FRANCESAS E PRÉ-ROMANTISMO PORTUGUÊS \\ Francofobia e Anglomania}

Álvaro MANUEL MACHADO

Universidade Nova de Lisboa

\section{Resumo}

A par da invasão, real e histórica, de Portugal por Napoleão nos anos 1807 - 1810 podemos constatar a existência de pelo menos duas evasões: uma real e histórica - a fuga da família real para o Brasil - e outra imaginária, mas igualmente real, a do nascimento do pré-romantismo português claramente dependente de uma imagem da França Revolucionária iluminista e enciclopedista, que se perderá com a invasão francesa. Em consequência, surge uma francofobia generalizada até à revolução liberal de 1820; a partir daí é antes a imagem idealizada da Inglaterra que cresce e cujas grandes obras começam a ser traduzidas, tendo frequentemente por original, como por ironia, as traduções francesas!

\section{Abstract}

While the real and historic invasions of Portugal by Napoleon were taking place, between the years 1807 and 1810, we can also note two other evasions: a real and historical one - the royal family's escape to Brazil - and an imaginary, but equally real, one: the birth of Portuguese Pre-Romanticism, clearly dependent on an Enlightenment and revolutionary image of the Revolutionary France, which will then be lost with the French invasion. As a consequence, a widespread francophobia arises, which would last until the liberal revolution in 1820. From then on, the idealized image of England grows stronger and English works start being translated from, ironically, French versions.

Palavras-chave: anglomania, evasões, francofobia, invasões, pré-romantismo.

Keywords: anglomania, evasions, francophobia, invasions, pre-Romanticism. 
Poderíamos, talvez, começar por jogar com as palavras a partir do engenhoso título deste Forum APEF 2010, relacionando invasões com evasões. De facto, com as invasões napoleónicas do território português, entre 1807 e 1810, relacionam-se directamente dois tipos de evasões: uma, historicamente muito concreta, é a evasão, ou mais propriamente, a fuga da família real para o Brasil; a outra, obviamente mais subjectiva, é a evasão através do imaginário romântico que nessa altura começa a formar-se. Quanto à primeira, não sendo eu historiador, apenas aludirei a essa evasão, neste breve intróito à minha conferência, referindo uma portentosa evocação (bem romântica, aliás, lembrando Michelet...) de Oliveira Martins, na sua fascinante História de Portugal (tomo II, Livro sétimo, capítulo II). Vale a pena, creio, citar esta tão expressiva evocação da decadência de Portugal em princípios do século XIX, sem dúvida actualíssima neste início do século XXI:

Quem faria face a Napoleão, cuja coorte atravessara a Espanha, e pisava já o solo português? Não seria o príncipe regente, nem a rainha doida, nem as altas classes ensandecidas, nem o povo faminto, indiferente, sebastianista. [...] A Nação, roída nos ossos [...], nem era já o esqueleto: era apenas o pó de um cadáver. Três séculos antes, Portugal embarcara, cheio de esperanças e cobiça, para a Índia; em 1807 (Novembro, 29) embarcava um préstito fúnebre para o Brasil. A onda da invasão varria diante de si o enxame de parasitas imundos, desembargadores e repentistas, peraltas e sécias, frades e freiras, monsenhores e castrados. Tudo isso, a monte, embarcava, ao romper do dia, no cais de Belém. Parecia o levantar de uma feira, e a mobília de uma suja barraca de saltimbancos falidos [...]. (Oliveira Martins, 1988: 237)

Mas dizia eu que, como sabem, não sou historiador, por mais que me tivesse deixado tentar por esta extraordinária evocação do historiador Oliveira Martins, tão literária, aliás. Por consequência, cabe-me analisar, no tempo das "invasões", a segunda "evasão", aquela que diz respeito à lenta, hesitante, sub-reptícia formação de um imaginário romântico na fase dita "pré-romântica" da literatura portuguesa, dividida entre a influência (palavra sempre perigosa, convenhamos...) predominantemente e genericamente francesa e a cada vez maior recepção, a nível estético mas também sócio-cultural, da imagem da Inglaterra. Questão sobretudo imagológica, portanto, como seria de esperar de um inveterado comparatista como eu...

\section{Pré-romantismo português e enciclopedismo francês}

Numa abordagem inicial da questão enunciada convirá, logicamente, tentar definir pré-romantismo em geral e pré-romantismo português em particular. Sem entrar em complexas especulações teóricas, evocarei algumas premissas que, aliás, já expus em 
várias obras ensaísticas e de pesquisa específica no domínio da Literatura Comparada, obras essas publicadas há já muitos anos, desde a primeira edição de As origens do Romantismo em Portugal (1979) e a publicação da minha tese de doutoramento de Estado, Les romantismes au Portugal. Modèles étrangers et orientations nationales, pela Fundação Gulbenkian em Paris (1986). Nessa primeira obra de 1979, citava uma definição (Machado, 1985: 14) desse grande teórico da literatura e, em especial, do Romantismo, que foi Georges Poulet, nos seus Études sur le temps : "Le préromantisme est assombri par la conscience de l'évanouissement de l'instant." (Poulet, 1968: 11). Esta definição continua a parecer-me exemplarmente subtil na sua rigorosa síntese, aplicando-se muito oportunamente ao conceito de literatura ligado a uma consciência do tempo, em particular do tempo histórico. No caso especificamente português, esse foi um tempo de profunda transição a nível geral da história das ideias, incluindo as ideias estéticas, entre a influência decisiva do enciclopedismo francês no final do século XVIII, o abalo provocado pelas invasões napoleónicas e o exílio de uma geração de intelectuais e escritores que prepararam a revolução liberal de 1820 , tudo isto paralelamente ao advento do primeiro romantismo.

No entanto, apesar destas mudanças, a verdade é que em Portugal (nem mesmo noutro país europeu) ninguém, então, utilizava o termo pré-romantismo nem sequer tinha consciência rigorosamente teórica dessa transição. De facto, o termo pré-romantismo só surgiu no domínio da teoria e da crítica literárias por volta de 1910, em França, na sequência e em paralelo com o termo pré-classicismo, utilizado cerca de vinte anos antes. A título de exemplo, cite-se a obra de Fortunat Stromski Tableau de la littérature française au 19e siècle, publicada em 1912, a qual defendia a teoria de evolução literária, em particular a evolução dos géneros, proposta por Brunetière. Aliás, outros teóricos franceses, como Lanson ou Mornet, já tinham tentado descobrir, a partir do final do século XIX, as origens do romantismo na literatura e também na vida social e cultural do final do século XVIII. Os primeiros comparatistas utilizam o termo pré-romantismo porque consideram o romantismo um fenómeno comum a todas as literaturas da Europa, fenómeno que passara por uma fase de transição, mais ou menos acentuada, dita pré-romântica. Esta teoria foi utilizada nos trabalhos de Literatura Comparada em França sobretudo desde a obra monumental de Paul Van Tieghem Le préromantisme. Études d'histoire littéraire européenne (1924-1930, 3 volumes). Se posteriormente, já nos anos 70 do século $X X$, foi posto em questão o conceito de pré-romantismo para designar um período literário preciso, como o fez Henri Peyre (1971) em Qu'est-ce que le romantisme? (embora ele reconheça que "faute de mieux" a designação "pré-romântico" para escritores como Rousseau seja adequada), temos de admitir que os sentimentos e as ideias que começaram a ser designados na Europa por 
românticos desde o século XVIII constituem os fundamentos periodológicos do Romantismo em geral, na sua sucessão de tendências estéticas, escolas e gerações literárias.

Assim, mesmo em Portugal, onde os modelos literários do classicismo greco-latino persistem até Garrett e Castilho, o significado desses modelos começa a integrar-se no Romantismo europeu em geral, como período literário mais ou menos claramente definido, como "visão do mundo" no sentido goethiano do termo, por volta de finais do século XVIII, com Bocage, por exemplo. Consequentemente, poderá admitir-se a hipótese da existência de um certo "pré-romantismo" português, com as suas características histórico-culturais próprias, no interior quer de um neo-classicismo tardio, quer de um culto das chamadas "Lumières" muito significativos, elementos que se prolongam até aos primeiros três decénios do século XIX, ou seja, até à segunda geração romântica.

Ora, para compreender a formação do Romantismo em Portugal a partir dessa fase de transição a que se poderá chamar "pré-romântica", isto é, entre finais do século XVIII e inícios do século XIX, altura das invasões napoleónicas, será imprescindível analisar a influência do enciclopedismo francês e, em particular, a recepção em Portugal de dois dos seus principais representantes, rivais, como se sabe: Voltaire e Rousseau. Para sermos muito sintéticos, digamos que essa recepção se relaciona directamente, para lá da diferença abissal entre os dois, com as ideias básicas do enciclopedismo e não com a libertação estética relativamente aos cânones neo-clássicos.

Como se difundem em Portugal essas ideias básicas do enciclopedismo francês, concentradas nas notícias e comentários sobre Voltaire e Rousseau? Principalmente através de periódicos, embora também através de prefácios a traduções, correspondência e livros de carácter ensaístico ou memorialístico. Assim, já na Gazeta de Lisboa, publicada desde 1715, subintitulada Notícias do estado do Mundo e redigida a partir de 1760 por Correia Garção, não sendo um periódico de carácter enciclopédico e ainda menos consagrado à criação literária, há referências a Voltaire e a Rousseau, este principalmente no início do século XIX. Com a publicação da Gazeta Literária, a partir de 1761, primeiro no Porto e depois em Lisboa, dirigida pelo cónego Francisco Bernardo de Lima, a recepção começa a tornar-se mais propriamente literária, predominando a imagem da França. As preferências do cónego vão ainda, como ele próprio diz, no "Discurso preliminar", para as “inimitáveis belezas da antiga Grécia e de Roma". E se à França é consagrado o primeiro número, releva-se não o pré-romantismo de Rousseau, autor menosprezado, mas o elevado sentido de criação neo-clássica, afirmando-se que os escritores franceses primam "no gosto, na boa disposição, método e ordem das matérias, em todos os assuntos úteis, como nos agradáveis". Por isso, não sendo feita nenhuma referência, na lista das novidades literárias francesas, a La nouvelle Héloïse, obra publicada em Janeiro de 1761, nem a Émile ou ao Contrat social, publicados respectivamente em Abril e Maio de 1762, fazem-se, em 
contrapartida, inúmeras referências a Voltaire, considerado pelo cónego "um dos maiores poetas do mundo", num comentário à Histoire de l'empire de Russie sous Pierre le Grand, publicado no número 19, de Novembro de 1791.

Se analisarmos, ainda que brevemente, os jornais ditos "enciclopédicos", já em finais do século XVIII, veremos que aí se difundem mais directamente as "Lumières", embora se privilegiem as ideias políticas em detrimento das teorias literárias. É o caso paradigmático do Jornal Enciclopédico, publicado mensalmente em Lisboa de Julho de 1779 a Maio de 1793, dirigido por Félix António Castrioto e Manuel Joaquim Henriques Paiva, dois homens de ciência, sendo o último professor de filosofia e médico consagrado. No artigo de "Apresentação" do jornal, refere-se claramente a importância do enciclopedismo: "Em Portugal não havia um Jornal Enciclopédico, tendo sido em todos os outros países de muito proveito as produções deste género. [...] Será este o Jornal da Nação: por meio dele podem uns comunicar aos outros as suas Luzes [...]." Assim, discute-se a cada passo a filosofia das "Lumières", em particular as ideias de D'Alembert, a partir do primeiro número. Voltaire e também Rousseau (parece que um não pode ser citado sem que o outro também o seja...) são considerados escritores importantes, embora devam ser lidos com extrema prudência, a nível estritamente literário e não como pensadores ou filósofos: "Estes dois autores devem ser lidos unicamente nas matérias que têm por objecto as belas-letras. Quando, porém, quiserdes com mão sacrílega e temerária tocar no santuário da religião, a sua memória deve ser abominada por todos os séculos." É caso para perguntar, perante este obscurantismo religioso, onde estava a atitude verdadeiramente iluminista deste primeiro jornal enciclopédico. No entanto, é indiscutível que contribuiu decisivamente para a recepção em Portugal, não só do enciclopedismo francês em geral, mas também de Voltaire e de Rousseau, abrindo a porta, embora timidamente, para uma visão já pré-romântica da literatura europeia.

Ainda no extremo final do século XVIII e prolongando-se até ao início do século XIX, deverá citar-se a obra de divulgação das ideias enciclopedistas de Luís Caetano de Campos, acusado por Pina Manique de ser um partidário da Revolução Francesa, compilador de textos em forma de folhetim, publicados periodicamente e assinados com 0 pseudónimo de Altina. Viagens d'Altina nas cidades mais cultas da Europa, e nas principais povoações dos Balinos, povos desconhecidos de todo o mundo é uma espécie de diário de viagem, entre real e imaginária (esta última parte influenciada pelas Viagens de Gulliver de Swift), publicado entre 1790 e 1798, em que o autor evoca sobretudo o meio intelectual parisiense. Na dedicatória ("À Humanidade") as reflexões do autor são bem à maneira de Rousseau, sobretudo pelas alusões a uma espécie de "mal du siècle" que se poderia qualificar de "pré-romântico": Luís Caetano de Campos antevê a passagem do século XVIII 
para o século XIX como uma espécie de ressurgimento da angústia que se repete de século em século e que, apesar das Luzes, trará a descrença na razão e no progresso.

De notar ainda, do mesmo autor, uma publicação em forma de jornal, ou mais propriamente, miscelânea, publicada mensalmente em Lisboa, entre 1803 e 1805, Bibliotheca Universal extrahida de muitos jornaes, e das Obras dos melhores Escritores antigos, e modernos, onde são referidos, além dos modelos gregos, "Mestres das Nações nas Ciências e nas Artes", os maiores escritores franceses: Montaigne, Montesquieu, Corneille, Racine, Voltaire e Rousseau. Na apresentação ("Prefação"), o autor expõe as suas ideias enciclopedistas bem rousseaunianas sobre a necessidade de atingir um conhecimento universal por parte do próprio escritor:" [...] abraçar, em resumo, a maior parte dos conhecimentos humanos; pelo menos dos que concorrem essencialmente para promover a prosperidade dos Estados. A Instrução Pública, os progressos das Ciências [...] são os grandes objectivos que devem ocupar a atenção de todo o escritor."

Vemos, assim, que entre o extremo final do século XVIII e o início do século XIX o espírito enciclopedista e iluminista proporcionava uma imagem privilegiada da França, preparando já a transição para o imaginário romântico, embora com todas as contradições de um pré-romantismo pleno de hesitações.

\section{Francofobia e anglomania no início do século XIX}

Tudo aquilo que, de certo modo (e vimos apenas alguns exemplos mais significativos), proporcionou a hesitante e lentíssima formação de um imaginário romântico em Portugal (a que poderíamos chamar "pré-romantismo"), relacionado principalmente, diria mesmo dependente, da imagem de uma França revolucionária, iluminista, enciclopedista, entre Voltaire e Rousseau, perde-se, ou pelo menos atenua-se com as invasões francesas. De facto, com as invasões napoleónicas desencadeia-se uma certa francofobia geral que vai prolongar-se pelo menos até à revolução liberal de 1820. Esta francofobia é acompanhada paralelamente por uma imagem idealizada da Inglaterra, imagem que começa por ser proveniente, a nível literário, do século XVII ou de um século XVIII ainda predominantemente neo-clássico. A prova é a primeira tradução de Paradise Lost de Milton pelo Padre José Amaro da Silva, publicada em 1789, tradução (ironicamente) feita do francês, isto é, seguindo a tradução (em prosa, datada de 1755) de Louis Racine, filho do grande Racine. No prefácio, por reacção, sem dúvida, à Revolução Francesa, o tradutor exalta a Inglaterra contra a França, dizendo que em Inglaterra "até mesmo a escória do povo 
lê, é onde os costumes são melhores, a Pátria é amada, a Religião mais observada e os Soberanos obedecidos e mais estimados."

É sobretudo a partir de 1807, ano em que, como se sabe, o exército de Junot invade o território nacional, que a galofobia se desenvolve. Assinale-se, antes de mais, o caso de José Daniel Rodrigues da Costa, autor satírico ferozmente anti-francês, com a publicação, em 1807, de Câmara Optica - Onde as vistas às avessas mostrão o mundo às direitas, série de doze "folhetos de três folhas de papel" publicados no início de cada mês. Desde a apresentação, o autor insurge-se contra os romances e novelas de origem francesa, fonte de "ruína total da mocidade". Outras obras do autor, em forma de opúsculos, reforçam a atitude francófoba. Por exemplo, no opúsculo intitulado Protecção à franceza, publicado em 1808, há estes versos claramente anti-napoleónicos e que dão uma imagem extremamente negativa da França:

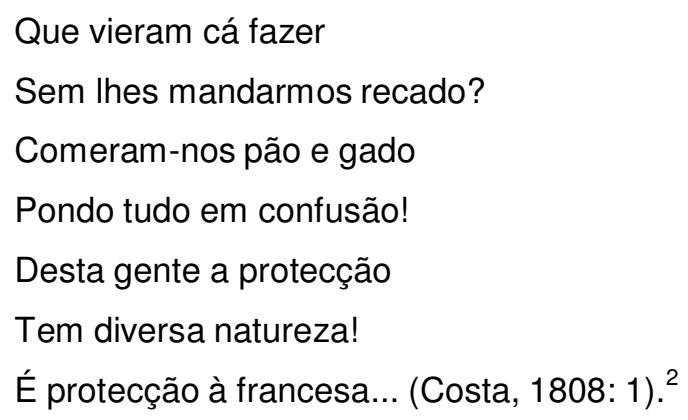

$\mathrm{Na}$ segunda parte desta diatribe galófoba, intitulada Embarque dos apaixonados francezes para o hospital do Mundo, ou Segunda parte da Proteç̧ão à franceza, datada igualmente de 1808, o autor evoca Junot como alegoria da falta de carácter do povo francês em geral:

\author{
Os Editais de Junot \\ Eram tais quais os dos touros \\ Mereciam um par de estouros \\ Pelas promessas que fez; \\ Mas promessas de francês \\ E contas de frialeiras \\ De ordinário vêm a dar \\ Em descompor e cardar (Costa, 1808: 3).
}

\footnotetext{
${ }^{1}$ Paraíso Perdido, poema heroico de Milton traduzido em vulgar do francez, Lisboa, Na Tipografia Rolandiana, 1789, 2 tomos.

${ }^{2}$ As citações são em português actualizado, apenas se conservando o título no original.
} 
Não me alongarei aqui na referência a inúmeros panfletos anti-napoleónicos, que têm sido amplamente estudados por historiadores e investigadores especializados neste período. Quero apenas referir ainda a obra de um economista e historiador da época, José Acúrsio das Neves, que evocou longamente e com detalhes as atrocidades cometidas pelas tropas francesas em História Geral da Invasão dos Francezes em Portugal e da Restauração deste Reino, obra publicada em Lisboa em 1810-1811 (5 volumes). Note-se nessa obra como o autor dá uma imagem extremamente negativa da França, para lá da própria circunstância histórica das invasões napoleónicas, exaltando, em contrapartida, a imagem da Inglaterra.

Este anglicismo evidencia-se até no período em que o enciclopedismo francês em geral e a obra de Rousseau em particular têm uma recepção positiva por parte de uma certa elite intelectual portuguesa, a dos exilados que vão depois participar na revolução liberal de 1820. É o caso sobretudo dos redactores de periódicos portugueses publicados em Londres, de entre os quais se destaca $O$ Investigador Portuguez em Inglaterra. Desde a apresentação, há referências precisas contra a Revolução Francesa. Além disso, escrevendo sobre literatura francesa relativamente à literatura inglesa, em geral, exalta-se sobretudo Walter Scott e no número de Dezembro de 1811 faz-se uma síntese nitidamente desfavorável para a literatura francesa da época em proveito da inglesa: "A literatura inglesa tem geralmente uma decidida superioridade sobre a francesa, tanto nas qualidades essenciais de sã doutrina, de pura e casta dicção, como na clareza do estilo, no elevado do sentimento, e no brilhantismo da imaginação original." Acrescenta ainda o redactor anónimo deste texto que os escritores parisienses têm "uma viciosa afectação de estilo, falsas ideias e ornatos fora de propósito", sendo a poesia francesa da época "uma repetição de lugarescomuns"3.

Refira-se ainda uma Ode ao invicto Wellington do francófobo José Agostinho de Macedo ${ }^{4}$. Mesmo no domínio das ideias filosóficas predomina a imagem da Inglaterra relativamente à da França: num longo estudo intitulado Prelecções filosóficas, Silvestre Pinheiro Ferreira evoca Condillac, mas considera Locke mais "sólido"

Num outro periódico importante publicado em Londres, entre 1808 e 1822, Correio Braziliense, as "Luzes" são muito mais inglesas que francesas. Logo no texto de apresentação do periódico, não assinado e datado de 1 de Junho de 1808, fala-se das "Luzes" em geral, sobretudo relativamente à imprensa, fazendo-se notar que, contrariamente à Inglaterra, elas são inexistentes em Portugal. Além deste texto de apresentação, outros ainda são extremamente significativos da interpretação dada à palavra

\footnotetext{
${ }^{3}$ O Investigador Portuguez em Inglaterra, Dezembro de 1811, vol. I, pp. 137-138.

4 Ibid., Abril de 1813, vol. VI, p. 180.

${ }^{5}$ ld., 1815 , nํXI, p. 47 e no XLII, p. 236.
} 
"Luzes" e à influência positiva do liberalismo inglês, evocando-se sobretudo a grandeza de Newton. Significativamente também, quer Voltaire quer Rousseau são ignorados nestas considerações sobre as "Luzes".

Ainda quanto aos periódicos publicados em Londres no período das invasões napoleónicas ou pouco depois e até à década de 20 do século XIX, deverá referir-se $O$ Portuguez; ou, Mercurio Politico, Commercial e Litterario, publicado entre 1814 e 1822, com grande difusão na capital britânica e mesmo em Lisboa, segundo o Dicionário Bibliográfico de Inocêncio (Silva, 1858 tomo III: 328). Desde o primeiro número, evoca-se negativamente a França a propósito da queda do império napoleónico, "contrário aos direitos dos homens e à liberdade dos povos [...]; oposto ao espírito público do nosso século, que é hoje (mais do que nenhum outro até aqui) fundado nos direitos da razão e da natureza." $E$ evocando-se a data de 10 de Novembro de 1807, data na qual "o governo francês, com o sistema e carácter de rapina e espoliação que the é peculiar, sequestrou todos os nossos navios", opõe-se a Inglaterra à França: "Esta potência [a Inglaterra] deve os primeiros elementos da sua grandeza à sabedoria da sua constituição [...]. A constituição francesa, ainda que modelada sobre a inglesa, está bem longe de ter a mesma perfeição." ${ }^{6}$ Num outro artigo, dedicado à Revolução Francesa, mas no qual se fala de arte em geral e de literatura em particular, chega-se a considerar a França um país pouco evoluído relativamente à Inglaterra: "Quanto ao atrasamento das belas-artes em França, é coisa confessada pelos mesmos sábios." Por outro lado, critica-se a influência perniciosa da França na língua e na literatura portuguesas. Àquilo a que se chama "falsa eloquência" revolucionária dos "Quixotes da Revolução Francesa", atribuem-se todos os defeitos da língua escrita e falada em Portugal: "o nosso Portugal também foi inçado desta praga que veio de França". ${ }^{8}$ Deverá referir-se ainda, no domínio da poesia de autores portugueses publicada por este periódico, uma Ode aos senhores Clubistas Portugueses de Londres, de Filinto Elísio, texto no qual a francofobia do autor é tão evidente como, em contrapartida, a sua imagem idealizada da Inglaterra, país no qual, segundo Filinto Elísio, se expande, no exílio, uma elite nacionalista que retoma a lição de Camões:

\section{E ainda há no Mundo quem dê preço e fama \\ À língua de Camões, nesta era esquiva, \\ Em que só reina intruso \\ Galicismo que enjoa!}

$\mathrm{Na}$ londinense terra, em campos armados

\footnotetext{
${ }_{7}^{6}$ O Portuguez; ou, Mercurio Politico, Commercial, e Litterario, Londres, no 1, 30 de Abril de 1814, pp. 107-108.

7 Id., no 7 , vol. II, p. 24.

8 ld., ibidem, pp. 29-30.
} 
Se abastecem de culto metro luso

Armas de forja vindas,

Que ergueram Camões preclaro. ${ }^{9}$

Sem pretender ser exaustivo, não posso, todavia, deixar de referir ainda a expansão da imagem da Inglaterra frequentemente oposta à da França nos periódicos literários próingleses publicados em Lisboa desde o início do século XIX, como, por exemplo, o Jornal de Bellas Artes, ou Mnemosine Lusitana, publicado entre 1816 e 1817. O ideal patriótico manifesta-se desde o primeiro número, no texto de apresentação, em que se evoca a luta dos portugueses contra os invasores franceses: "desde 1808 até ao presente tem sido objecto de admiração geral a acção patriótica dos Portugueses, [...] trazendo-nos à memória aquelas épocas em que os Portugueses foram assombro do mundo [...]". E num outro texto evoca-se ainda a batalha do Buçaco. Entre várias alusões elogiosas aos ingleses e à cultura britânica em geral, há no número 10 um soneto anónimo que comemora a chegada de Lorde Wellington a Lisboa. E mesmo um intelectual afrancesado como o Conde da Barca publica neste periódico traduções dos escritores pré-românticos ingleses Dryden e Gray. ${ }^{10}$

Assim, vemos que, durante e logo após as invasões napoleónicas, a Inglaterra tornase o exemplo supremo do país europeu "civilizado", harmonizando liberdade política e evolução sociocultural, opondo-se às "barbaridades" francesas. Esta imagem, de uma galofobia que alimenta a anglomania, favorece cada vez mais a recepção de autores préromânticos ingleses, traduzidos e comentados desde finais do século XVIII. É o caso paradigmático de Young.

Este importante poeta pré-romântico inglês é traduzido em Portugal desde 1782, numa selecção antológica das Night Thoughts intitulada precisamente Noites Selectas de Young. A prova de que o francesismo ainda imperava nessa altura e que poucos conheciam bem a língua inglesa, é que a tradução foi feita segundo a tradução francesa do préromântico Letourneur, publicada em Paris em 1769. O tradutor, José Manuel Ribeiro Pereira, faz preceder a sua tradução, aliás bastante medíocre, por um prefácio interessante a nível da estética da recepção e da Literatura Comparada. José Manuel Ribeiro Pereira, que, como ele próprio se apresenta, é "bacharel formado na Faculdade de Leis, actualmente empregado ao serviço de Sua Majestade Fidelíssima no lugar de Secretário da Companhia do Pará e Maranhão", começa por dizer no seu "Discurso preliminar" que Young "excessivamente inimigo de tudo o que the parecia imitação, inteiramente abandonou a imaginação a si mesma". Poder-se-ia pensar que isto representava uma constatação anticlássica louvada pelo tradutor. Nada disso. Logo a seguir, o tradutor acrescenta:

\footnotetext{
${ }^{9}$ Id., no 2, vol. I, 10 de Junho de 1814, p. 183.

${ }^{10}$ Cf. Jornal de Bellas Artes, ou Mnemosine Lusitana, Lisboa, Na Impressão Régia, 1817, no 20, pp. 312-319 e no 21, pp. 329-335.
} 
[...] o Poema das Noites deste grande homem contém em si numerosos defeitos, mas nem por isso deixa de ser a mais sublime Elegia que se tem feito sobre as misérias da condição humana e o mais luzido monumento, onde as grandes belezas da Poesia brilham unidas com as grandes verdades da Moral e da Religião. ${ }^{11}$

Este moralismo torna-se ainda mais evidente quando, depois de uma "descrição do seu nascimento, vida e morte", o tradutor põe em relevo o lado exemplar de Young, não como modelo literário pré-romântico que ele de facto foi, mas sim como modelo de moralidade religiosa extremamente convencional: [...] foi para os seus patrícios um exemplo dos costumes e da piedade primitiva. A sua vida pregava tão eloquentemente a virtude como os seus escritos, nos quais é fácil ver que ele falava do coração." ${ }^{12}$ As reservas postas pelo tradutor, que encontra defeitos naquilo a que ele chama a "monotonia" da obra (não percebendo o elemento inovador da linguagem pré-romântica, baseado na utilização de imagens obsessivas e repetitivas da noite, cortando aqui e ali, arbitrariamente), leva-o também a cortar certas passagens consideradas perigosas para a ortodoxia religiosa do catolicismo em Portugal:

Estes são os bocados do original que omiti, como também algumas declarações contra o Papa, próprias da boca dum protestante, e algumas passagens que unicamente pertenciam à Teologia e aos Dogmas da Revelação; e igualmente algumas proposições erróneas e refutadas pela Igreja. ${ }^{13}$

No plano puramente estético, a própria tradução de Letourneur é criticada por ter os mesmos "defeitos" de "repetição", ou seja, "defeitos" pré-românticos, prolixidade, excesso daquilo a que o tradutor português chama de "sentimento duma activa melancolia" ${ }^{14}$. Enfim, Ribeiro Ferreira releva a orientação nacional do trabalho do tradutor, considerando que devia fazer "mais uma paráfrase que uma tradução, procurando tirar do Young inglês e do Young francês um Young português que possa agradar à minha nação". ${ }^{15}$

Esta atitude predominantemente nacionalista vai marcar toda a recepção de obras pré-românticas estrangeiras no período de formação do romantismo em Portugal. Mas ela tem nuances, desde a referida primeira tradução de Young, ainda nitidamente dominada pelo espírito neo-clássico (além do dogmatismo religioso), até às traduções, adaptações e

\footnotetext{
${ }_{11}^{11}$ Noites Selectas de Young, Lisboa, Na Of. De Simão Tadeu Ferreira, 1782, tomo I, p. II.

12 Id., ibid., p. X.

${ }^{13}$ Id., Ibid., pp. XII-XIII.

${ }_{15}^{14}$ Id., Ibid., p. XIII.

${ }^{15}$ Id., Ibid., pp. XIV-XV.
} 
paráfrases feitas a partir do mesmo Young já entre o extremo final do século XVIII e o início do século XIX, coincidindo com uma imagem da Inglaterra que se sobrepõe à da França.

Fiquemos ainda com Young e lembremos, antes de mais, o caso da Marquesa de Alorna, que conhecia Young antes mesmo da primeira tradução portuguesa de Night Thoughts. Muito presa ao neo-classicismo, a Marquesa de Alorna mistura Horácio com o poeta pré-romântico inglês. Evocando as preferências poéticas de Alcipe, seu pseudónimo arcádico, escreve: "[Young e Horácio] as duas influências antagónicas entre que o espírito de Alcipe se debate" (Marquesa de Alorna, 1941b: 48). Finalmente, ela decide-se por Young, como diz numa carta ao pai enviada do convento de Chelas: "Resolvi-me a intentar pelo gosto de Young um poema sobre a morte" (Marquesa de Alorna, 1941a: 23). Mas fá-lo com prudência de linguagem, para não ficar "cousa ofensiva dos ouvidos", cultivando imagens fúnebres de sepulcros e cemitérios ao luar, além de "feias Parcas", fazendo mais pensar num ultra-romantismo avant la lettre, desprovido de imaginação original e de pensamentos metafísicos. Exilada em Londres, entre 1803 e 1814, a Marquesa de Alorna, vítima de Pina Manique e das invasões napoleónicas, não só consagra Young e outros escritores ingleses, que traduz, como Gray, Ossian, Dryden ou o Thomson de The Seasons, mas também exalta a constituição inglesa, relacionando-se com Madame de Staël.

Devemos ainda referir dois outros casos de escritores portugueses pré-românticos ligados a um certo anglicismo a partir sobretudo da leitura de Young, além de outros clássicos e pré-românticos ingleses: José Anastácio da Cunha e Bocage. No caso do primeiro, para lá da evidente influência de Young na sua obra poética, o grande contributo dado para a formação do romantismo em Portugal é o interesse por Shakespeare, modelo mítico de todos os grandes românticos europeus, desde o primeiro romantismo alemão, como se sabe. No caso de Bocage, a leitura de Young foi decisiva para a criação de um certo imaginário nocturno, sobretudo nos sonetos da última fase. Todavia, em Bocage, a "Noite amiga", "retrato da morte", como diz num desses sonetos, não chega a atingir uma verdadeira dimensão metafísica, limitando-se a ser pretexto para uma monotonamente lúgubre e superficial alegoria. A este propósito, Vitorino Nemésio, analisando a influência de Young em Bocage e, em geral, a da literatura inglesa no nosso pré-romantismo, observa com extraordinária e oportuna ironia: "o terrífico fica pelos qualitativos, sem que o vejamos vivo: luar, florestas, mochos que "guincham" e deviam piar" (Nemésio, 1970: 25).

Outros elementos nos permitem reforçar a ideia de uma expansão da imagem da Inglaterra e da literatura inglesa no início do século XIX em Portugal, acompanhada frequentemente por uma certa galofobia, sobretudo no que diz respeito às traduções, publicadas quer em periódicos quer em volume. Refiro apenas alguns autores, de entre os mais importantes: Byron, cujas traduções são acompanhadas por um byronismo que se expande a partir de 1812 e atinge o seu ponto culminante por volta de 1840; Wordsworth, 
que defende Portugal contra os franceses em The Convention of Cintra (1809); Richardson, traduzido em Portugal desde 1790 (Pamellla Andrews, reeditada em 1807) e sobretudo divulgado a partir da tradução (feita segundo a tradução francesa de Letourneur) do seu romance Clara Harlowe, publicada em 15 volumes entre 1804 e 1818; Fielding, autor de Journal of a Voyage to Lisbon, obra datada de 1755 mas só traduzida para português em 1805, e do célebre romance Tom Jones, publicado em Inglaterra em 1749 mas cuja tradução portuguesa só é publicada em 1812; enfim, Walter Scott, modelo obsessivo de Herculano, traduzido desde 1803 e mais frequentemente a partir de 1811. Note-se ainda, na tradução que o Conde de Aguiar (D. Fernando José de Portugal e Castro) publica em 1810 de Essay on Criticism de Pope, as críticas feitas no prefácio à cultura francesa, sobretudo no que diz respeito às traduções: segundo ele, o tradutor francês "apropriou os pensamentos do seu modelo e os vestiu de tal maneira à francesa [...] que quase aí se desconhecem". ${ }^{16}$ Esta atitude parece-me bem significativa de uma anglomania em plena expansão, acompanhada por uma galofobia cuja origem está sobretudo nas invasões napoleónicas.

É tempo de concluir. E talvez nenhum outro autor, no início do romantismo português, como Garrett nos dê a medida exacta desse rasto de francofobia vinda da época das invasões francesas e que desencadeou todo o processo de uma certa anglomania dominante nessa primeira geração romântica. Sobretudo o Garrett do exílio londrino. Como é óbvio, seria oportuno (e, aliás, já o fiz por diversas vezes) aprofundar aqui a atitude, tantas vezes contraditória, de Garrett relativamente quer à França quer à Inglaterra. Mas o tempo não o permite. Assim, limitar-me-ei a referir apenas um exemplo dessa oscilante atitude, exemplo de galofobia e de anglomania, uma imagem da Inglaterra como "pátria da lei, senhora da justiça", evocando o seu primeiro exílio londrino de 1823, no início do poema Camões, imagem oposta às imagens, no seu segundo exílio, de uma França cheia de "volúvel, leviana gente":

Vem ; não receies a acintosa mofa

Desta volúvel, leviana gente

Largo! aos mares:

Livres corramos sobre as ondas livres

[...] Aí d'entre as vagas

Surge a princesa altiva das armadas,

Pátria da lei, senhora da justiça,

${ }^{16}$ Ensaio sobre a Critica, de Alexandre Pope, traduzido em Portuguez pelo Conde de Aguiar com as notas de José Warton, do traductor e de outros; e o comentário do Dr. Warburton, Rio de Janeiro, Na Impressão Régia, 1810. Prefácio citado, pp. I a VII. 
Couto da foragida liberdade.

Salve, Britânia, salve, flor dos mares,

Minha terra hospedeira, eu te saúdo! (Garrett, 1943: 18-19)

Nada de mais oposto a esta imagem garrettiana de uma Inglaterra idealizada, justa, libertadora, acolhedora de exilados políticos e leal aliada de Portugal, do que a imagem que da Inglaterra dá Oliveira Martins, na sequência da evocação, por mim já analisada no intróito, das invasões francesas, na sua inicialmente citada História de Portugal:

Éramos o instrumento, o servo, a mula de carga da Inglaterra, desde que ela nos arrebatara das mãos do francês. Beresford, nomeado general do nosso exército, foi de facto um procônsul, um rei. [...] o pensamento do inglês não era defender Portugal, mas sim destruir Napoleão com os soldados portugueses. [...] o inglês que, desde 1640, e principalmente desde 1703, reinava mercantilmente sobre a inépcia portuguesa; o inglês, que agora tinha em Portugal uma cousa sua, um Gibraltar e um exército, sentia ainda o apetite de acompanhar o príncipe-regente ao Brasil, para o defender na América, apropriando-se do resto do império e da riqueza nacional. [...] Quando Napoleão caiu e voltou a paz, deu-se o balanço à fortuna portuguesa. Era um sudário de miséria e solidão. (Oliveira Martins, 1988: 246-250)

Como se sabe, esta imagem negativa da Inglaterra deteriorou-se ainda mais com o Ultimatum inglês de 1890, sendo acompanhada por uma espécie de francofilia generalizada. Todavia, afinal, a imagem de um país estrangeiro, imagem sociocultural e literária mas dependente sobretudo da história, não será, como o mito, o domínio privilegiado da luta entre memória e esquecimento? A verdade é que, para lá dos acontecimentos históricos imediatos, quer as invasões francesas, ocorridas em pleno período pré-romântico, quer acontecimentos posteriores ao longo do século XIX português, reactivaram uma cíclica consciência da decadência nacional no interior de toda a evasão desencadeada pelo imaginário romântico. E neste sentido, poderá dizer-se que só a Geração de 70 redimensionou e corrigiu, pela sua própria consciência crítica e autocrítica, essa consciência de decadência nacional que marcou muito particularmente o nosso século XIX, sobretudo a partir das invasões francesas. Fê-lo, ora através da ironia queirosiana, ora com o sentido do trágico anteriano, ora ainda com o dramatismo de Oliveira Martins. Fê-lo repensando e reavaliando todo o percurso do nosso hesitante romantismo nos seus contactos com culturas estrangeiras, desde o período pré-romântico, dando a essas imagens imediatas da história um significado mais complexo pela forma, essencialmente simbólica, de repensar Portugal. 


\section{Bibliografia}

CostA, José Daniel Rodrigues da (1808). Protecção à franceza. Lisboa.

Ensaio sobre a Critica, de Alexandre Pope, traduzido em Portuguez pelo Conde de Aguiar com as notas de José Warton, do traductor e de outros; e o comentário do Dr. Warburton. (1810). Rio de Janeiro: Impressão Régia. 1810.

GARRETT, Almeida (1943). "Camões" e "D. Branca". Introdução seleção e notas de António José Saraiva. Lisboa: Livraria Clássica Editora.

Jornal de Bellas Artes, ou Mnemosine Lusitana (1817), no 20, № 21. Lisboa: Impressão Régia.

MACHADO, Álvaro Manuel (1985). As origens do Romantismo em Portugal. 2ª ed. Lisboa: ICALP.

MARQUESA DE ALORNA (1941a). Inéditos - Cartas e outros escritos. Seleção, prefácio e notas de Hernâni Cidade. Lisboa: Livraria Sá da Costa.

MARQuesa de ALORNA (1941b). Poesias... Seleção, prefácio e notas de Hernâni Cidade. Lisboa: Livraria Sá da Costa.

NEMÉSIO, Vitorino (Introdução, seleção e notas de) (1970). Bocage, Poesias várias. 3 $3^{\mathbf{a}}$ edição emendada. Lisboa: Livraria Clássica Editora.

Noites Selectas de Young (1782). Tomo I. Lisboa: Of. De Simão Tadeu Ferreira.

OliVeIRA MARTINS, J. P. (1988). História de Portugal. Lisboa: Imprensa Nacional/Casa da Moeda.

O Investigador Portuguez em Inglaterra, 1811-1815.

O Portuguez; ou, Mercurio Politico, Commercial, e Litterario, Londres, nํ1, 30 de Abril de 1814.

Paraíso Perdido, poema heroico de Milton traduzido em vulgar do francez (1789). 2 tomos. Lisboa: Tipografia Rolandiana.

PeYRE, Henri (1971). Qu'est-ce que le romantisme. $2^{2}$ ed. Paris : PUF.

POULET, Georges (1968). Études sur le temps humain IV - Mesure de l'instant. Paris: Plon.

SILVA, Inocêncio Francisco da (e Brito Aranha, Gomes de Brito, Álvaro Neves) (1858-1923).

Diccionario Bibliographico Portuguez. Lisboa: Imprensa Nacional. 
